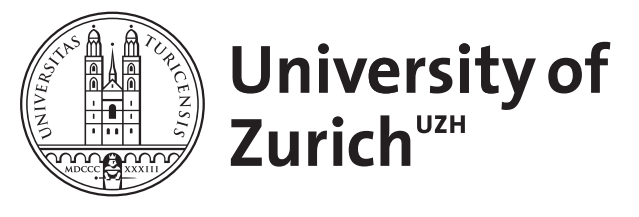

\title{
Radical or incremental: Where does RD policy hit?
}

\author{
Beck, Mathias ; Lopes-Bento, Cindy ; Schenker-Wicki, Andrea
}

\begin{abstract}
This study investigates the efficacy of public RD support. Compared to most existing studies, we do not stop at substitution effects or general innovation outcome measures, but we are interested in knowing where the policy effect is highest: on innovation close to the market (i.e. incremental innovation) or on innovation that is still far from the market and hence more risky and radical. Using firm level data from the period 1999 to 2011, we find that the policy hits where the market failure is highest, that is, for radical innovation. Taking into account that the Swiss funding agency encourages collaboration, we find no evidence that the impact of the policy is positively effected by various RD collaboration patterns.
\end{abstract}

DOI: https://doi.org/10.1016/j.respol.2016.01.010

Posted at the Zurich Open Repository and Archive, University of Zurich

ZORA URL: https://doi.org/10.5167/uzh-111032

Conference or Workshop Item

Presentation

Originally published at:

Beck, Mathias; Lopes-Bento, Cindy; Schenker-Wicki, Andrea (2015). Radical or incremental: Where does RD policy hit? In: The 13th Annual INTERNATIONAL INDUSTRIAL ORGANIZATION CONFERENCE, Boston, 24 April 2015 - 26 April 2015, s.n..

DOI: https://doi.org/10.1016/j.respol.2016.01.010 


\title{
Radical or incremental: Where does R\&D policy hit?*
}

\author{
Mathias Beck ${ }^{a}$, Cindy Lopes-Bento ${ }^{\text {a,b,c }}$ and Andrea Schenker-Wicki ${ }^{\mathrm{a}}$ \\ a) Univesity of Zurich \\ b) K.U.Leuven, Dept. of Managerial Economics, Strategy and Innovation \\ c) Centre for European Economic Research (ZEW), Mannheim
}

This version: September 2014

\begin{abstract}
This study investigates the efficacy of public R\&D support. Compared to most existing studies, we do not stop at substitution effects or general innovation outcome measures, but we are interested in knowing where the policy effect is highest: on innovation close to the market (i.e. incremental innovation) or on innovation that is still far from the market and hence more risky and radical. Using firm level data from the period 1999 to 2011, we find that the policy hits where the market failure is highest, that is, for radical innovation. Taking into account that the Swiss funding agency encourages collaboration, we find no evidence that the impact of the policy is positively effected by various $R \& D$ collaboration patterns.
\end{abstract}

Keywords: $\quad$ R\&D subsidies; collaborative innovation; diversity; innovation performance; radical innovation; incremental innovation; policy evaluation; treatment effects.

JEL-Classification: C14, C30, H23, O31, O38

\section{Authors' contact:}

Mathias Beck, University of Zurich, Department of Business Administration, Plattenstrasse 14, CH-8032 Zurich, Switzerland. E-mail: mathias.beck@business.uzh.ch

Cindy Lopes-Bento, K.U.Leuven, Department of Managerial Economics, Strategy and Innovation, Naamsestraat 69, 3000 Leuven, Belgium. E-mail: cindy.lopesbento@kuleuven.be

Andrea Schenker-Wicki, University of Zurich, Department of Business Administration, Plattenstrasse 14, CH-8032 Zurich, Switzerland. E-mail: andrea.schenker@business.uzh.ch.

*Acknowledgments: The authors are grateful to the KOF Swiss Economic Institute at ETH Zurich for access to the data. Furthermore, the authors thank Ulrich Kaiser as well as participants of the ISPIM Conference and the Zurich Workshop on Economics for useful comments. Lopes-Bento gratefully acknowledges financial support by the National Research Fund, Luxembourg, cofunded under the Marie Curie Actions of the European Commission (FP7-COFUND). 


\section{INTRODUCTION}

Innovation is largely acknowledged to be a main factor of a country's sustainable and competitive development (Aghion \& Howitt, 1992; Griliches, 1979; Romer, 1990). It is also recognized that due to market imperfections, firms are unlikely to reap all the benefits from their research, leading to un underinvestment in $R \& D$. Therefore, governmental support is a widely accepted means to foster socially valuable innovation.

The concept of market imperfection goes back to Nelson (1959) and Arrow (1962), who state that firms do not invest the socially desired level in R\&D efforts due to market imperfections including limited approbiability, lower private than social returns, financial market constraints, high risks about technological standards, high costs and high uncertainty of R\&D projects and further forms of negative externalities (Martin \& Scott, 2000). The implications of this under-investment in $\mathrm{R} \& \mathrm{D}$ have encouraged policy makers to establish public support mechanisms. In the current paper, we are interested in one particular type of support, namely direct funding for $\mathrm{R} \& \mathrm{D}$ projects. More precisely, we aim at contributing to the an on-going debate about the returns of public R\&D funding (Jones \& Williams, 1998; Salter \& Martin, 2001), and in particular about whether public money is used in the most efficient way (David \& Hall, 2000; David, Hall, \& Toole, 2000; Klette, Møen, \& Griliches, 2000). In order to do so, we investigate the impact of a public support policy on outcome characteristics that have so far largely been ignored. Specifically, we analyse where the policy effect is highest: on $\mathrm{R} \& \mathrm{D}$ projects concerning research close to the market (i.e. incremental innovation) or on $\mathrm{R} \& \mathrm{D}$ projects concerning more basic and hence radical and risky innovation. Based on the market failure theory stipulating that under-investment in $R \& D$ may be particularly pronounced for more basic and radical innovations because of the high uncertainty linked to 
such projects, one would expect to see an effect of public support on radical rather than on incremental innovation. Furthermore, given that funding agencies want to stimulate socially desirable projects that would not be undertaken without public support, one would assume that agencies target more basic and radical research in particular. Yet, so far it has not been investigated empirically whether such selection mechanisms are reflected in the impact of publicly induced $R \& D$ on product innovation. As a first and main contribution, this paper therefore disentangles the effects of the policy according to the degree of novelty of the products, thereby estimating if the policy effect is highest where the market imperfections are more pronounced. Going further, we analyse these effects in light of various collaboration patters, as collaboration is typically encouraged by funding agencies and hence constitutes an important part in the funding policy. While the impact of subsidized collaborating firms has been analysed before (see for instance Czarnitzki et al. (2007) or Hottenrott and Lopes-Bento (2014a)), scholars have not differentiated according to the type of partner, respectively to partner diversity in this context. Accounting for the diversity of partners a firm can collaborate with (i.e. vertical, horizontal or diagonal), this paper sheds light as to whether, on the one hand, (the type of) collaboration partners of a firm impacts input additionality and, on the other hand, (the type of) collaboration partners impacts subsequent product innovation, differentiating between incremental and radical innovation. Finally, the present study is undertaken on a representative sample of Swiss firms. Even though Switzerland is considered an innovation leader among the OECD, it has not received as much attention as many other countries on this subject.

We base our analysis on a representative firm-level data-set covering the period between 1999 to 2011 of the Swiss innovation survey. Contrasting our findings from econometric treatment effects estimations and heterogeneity robust tobit models to a series of robustness checks, we find that, on average, the receipt of an $R \& D$ subsidy translates into higher $R \& D$ 
investment. In terms of output additionality, we find that the impact of public support is only significant for radical innovation. No impact of policy-induced R\&D is found for incremental innovation. In contrast, collaborative R\&D only displays significant results on incremental innovation. Contrary to expectations, we do not find evidence that the impact of the policy is improved through collaboration. We can thus conclude that while the Swiss public R\&D policy is efficient in terms of stimulating R\&D investment and in terms of intervening where the market imperfections are highest, the current tendency of encouraging R\&D collaboration does not seem to enhance such effects.

The remainder of the paper is structured as follows: section two presents the Swiss innovation policy. Section three puts our research question into the recent literature. Section four outlines the methodology. The data is explained in section five. Section six presents the results and section seven concludes.

\section{INSTITUTIONAL CONTEXT OF THE SWISS INNOVATION POLICY}

Many countries have launched innovation policy programs to promote national innovativeness and competitiveness. An outstanding performance in $R \& D$ and innovation activities is considered an important factor not only for economic growth but also for a sustainable economic perspective in terms of employment, ecology and education for a modern knowledge society. In Switzerland, public funding of R\&D has increased by 5.3\% between 2000 and 2010. In 2010, the financial budget for appropriations or outlays dedicated to R\&D covers an amount of 4.6 billion CHF, which corresponds to $0.81 \%$ of the country's GDP. In an international comparison (measures from 2008), Switzerland holds the eleventh rank of 31 OECD countries with public R\&D funding corresponding to $0.73 \%$ of the country's GDP. The United States (1.02\%) and Finland $(0.98 \%)$ are on the top positions of the public funding per GDP ratio (FSO, 2012). 
In Switzerland there are two major R\&D funding agencies providing public grants for $R \& D$ programs and projects - the Swiss National Science Foundation (SNSF) and the Commission for Technology and Innovation (CTI) - with a total budget of 1.0 billion CHF in 2010. While the SNSF is mainly in charge to provide public grants to $R \& D$ projects or programs conducted by public research institutes or by individual researchers, the CTI is responsible funding agency for $\mathrm{R} \& \mathrm{D}$ projects in the private sector, with a total budget of $118 \mathrm{Mio} \mathrm{CHF}$ in 2010. As a consequence, the subsidies under review in this study mainly stem from the CTI.

The subsidy scheme is not based on calls for proposals, but firms can apply with R\&D projects all year long. Likewise, there are no restrictions in terms of technology fields supported by the agencies. Nonetheless, the CTI has the general goal to stimulate innovation in SMEs and encourages joint $R \& D$ activities between private companies and public research institutes. The focus of the policy is two-fold: on the one hand, the agency provides support for applied and market-oriented $\mathrm{R} \& \mathrm{D}$ projects which lead to the generation of new technologies and insights that are realizable in short or medium term to strengthen the country's innovation position (CTI, 2011). On the other hand, the CTI also supports high risk but promising projects, including early stage pilot installations. Applicant firms have to provide a detailed description on the project's impact and a clear business and financial plan. The ex-ante evaluation is done by external and internal referees, which evaluate the expected effectiveness of the R\&D projects. In 2010, 780 projects were evaluated, and $343(44 \%)$ projects have been retained for public support (CTI, 2013). In case of a positive evaluation, the firm receives a subsidy in form of a matched grant, where the public funding typically covers up to approximately $50 \%$ of the expected costs (in 2010 the average subsidy rate was of $41 \%$ of the project costs) (CTI, 2011, 2013). In 2010, 667 firms are involved in co-funded R\&D projects, among which almost three quarters (74\%) were SMEs (CTI, 2013). The 
average project duration in the period 2009-2011 was of 20 months and the average project size amounted to 682.2 thousand Swiss francs. ${ }^{1}$

\section{OUR RESEARCH QUESTION IN LIGHT OF RECENT LITERATURE}

Empirical evidence on R\&D subsidies is common in the literature to date. In terms of input additionality, it has been shown that the null hypothesis of full-crowing out can be rejected in the vast majority of cases. Indeed, Hall and Maffioli (2008) have found that in empirical literature since 2000, total crowding out effects were only found for the US Small Business Innovation Research (SBIR) program, analysed by Wallsten (2000). ${ }^{2}$ In terms of output additionality, evidence confirms that subsidies have a positive impact on innovation performance, as measured for instance by patent outcome (see e.g. Czarnitzki and Hussinger (2004) or Czarnitzki and Licht (2006) for a sample of German firms) or novelty sales Czarnitzki and Lopes-Bento (2011).

What has not received attention in the literature so far however, is the impact of $R \& D$ subsidies on the type of the subsequent product novelty. Put differently, while some studies have investigated whether publicly induced $R \& D$ investment translates into marketable products (see for instance Hottenrott and Lopes-Bento (2014a)), those studies have not differentiated between the degree of novelty of products. That is, they have not made a difference between incremental and radical innovation. However, this influence can constitute an important choice in terms of innovation strategy for the firm as well as in terms of evaluation strategy for the policy maker. Indeed, when a firm decides to invest in innovation, it can either opt for a safer strategy by favouring investment in incremental innovation, or it can opt for the riskier strategy by investing in radical R\&D. Even though incremental innovation is unlikely to dramatically change firm performance, sustained incremental innovation is required to prevent a firm from falling behind its competitors and ensuring its prospects of long-term survival. Radical innovation, on the other hand, has the 
potential to push the technological frontier of a firm or even sector and may allow a firm to enter new markets. While the latter type of innovation has a higher potential to have a fundamental impact on firm performance, it is also involved with higher costs and substantial risks. It may thus well be that projects of radical $R \& D$ nature are less likely to be undertaken as firms have to be willing to bear the inherent risk of this endeavour. Since the assumption is that firms are often risk-averse, this could lead to a sub-optimal allocation of risk, meaning that there will be discrimination against projects of more radical or risky nature (Arrow \& Lind, 1970). One could thus assume that firms seek funding primarily for this type of project and that it is also this type of project that is favoured by a funding agency. Yet, in the short and medium-term, output from less radical projects may be more visible, both for the firm as well as for the policy maker accountable for the public expenditures. Hence, it is difficult to predict ex-ante where the policy effect will be highest and whether the selection process of the funding agency is efficient in light of the type of innovation in which the additional investment will be destined to.

Finally, it has long been acknowledged that R\&D collaboration may play an important role, for the type as well as the success of innovation projects. Allowing to limit outgoing spillovers by internalizing them to the research consortium and providing access to complementary know-how and resources of partnering firms, it has been shown that R\&D collaboration can enhance private R\&D activities substantially (see for instance D'Aspremont \& Jacquemin, 1988; DeBondt, 1997; Kamien, Muller, \& Zang, 1992; Katz, 1986). Empirical findings confirm the positive effects of R\&D collaboration on innovation input and output, and emphasize the importance of openness towards external sources of knowledge and external partners (Becker \& Dietz, 2004; Belderbos, Carree, \& Lokshin, 2004b; Leiponen \& Helfat, 2010). In line with our emphasis on the importance of the type of innovation, further studies acknowledge the existence of heterogeneity in the motives and objectives for 
collaboration (Belderbos, Carree, Diederen, Lokshin, \& Veugelers, 2004a; de Faria, Lima, \& Santos, 2010; Faems, Van Looy, \& Debackere, 2005; Kaiser, 2002). Differentiating between four types of cooperation partners-competitors, suppliers, customers, and universities and research institutes-Belderbos et al. (2004a) demonstrate in their study that collaboration with competitors and suppliers aims at fostering incremental innovation while collaboration with universities and competitors intends to pursue more market or radical innovations. However, collaboration in R\&D is also linked to certain risks, like for instance collusion in the product market, and the risks of leaking out knowledge due to outgoing spillovers (e.g. Czarnitzki et al., 2007). Furthermore, to be able to fully benefit from collaboration, a firm needs to build up specific competences and maintain a fruitful level of absorptive capacity to manage and coordinate collaborations efficiently and effectively. Otherwise, outgoing spillover effects might be higher than incoming spillover effects for some partners of the consortium, leading to the costs of collaboration being higher than the gains. This may be especially true when a firm builds on a great diversity of external knowledge sources and collaboration partners, as has been pointed out by Laursen and Salter (2006), and Beck and Schenker-Wicki (2014). Finally, incomplete contracts resulting from poor bargaining and costs of disclosure that are inherently linked to collaboration may render collaborative R\&D costly if collaboration exceeds a certain threshold (Hottenrott \& Lopes-Bento, 2014b).

While each of these topics has received a lot of attention in the literature when considered individually, less attention has been attributed to how they interact. Even though some studies analyse the impact of subsidized R\&D collaboration on output additionality, these studies do not differentiate between the number or type of partners, nor between the degree of novelty of the outcome. ${ }^{3}$ Hence, a series of crucial policy characteristics remain pending. The current analysis aims at filling this gap, as we argue that both these aspects are not only essential for policy makers but also for firm managers. 
From a policy point of view, it is essential to know if the ex-ante project evaluation is appropriate to prevent firms from crowding-out of private $R \& D$ expenditure due to public R\&D funding. Therefore, in a first step, we investigate the effectiveness of the policy scheme and test if the subsidy leads to input additionality. In a second step, we analyse how this policy induced $R \& D$ expenditures translate into innovation output, differentiating between radical and incremental innovation. Even in case of positive input additionality, it remains unclear if the publicly induced $R \& D$ is as productive as the privately induced $R \& D$. In case of equal (or even higher) productivity, it remains so far undefined whether the impact is highest where market failures are strongest. Finally, our analysis is done taking the number (and type) of collaborating partners into account, given that policy increasingly encourages firms to collaborate in their R\&D activities. It thus seem crucial that policy makers know whether this policy achieves its goal or whether the costs of collaboration undermine its benefits in certain cases.

In contrast to most policy evaluation studies, our analysis also allows drawing conclusions from a managerial perspective. Indeed, from a managerial perspective, it is important for project managers to know where the impact of $R \& D$ subsidy is highest in order for them to best adapt grant applications to innovation strategies. Likewise, knowing whether input and/or output additionality is enhanced through collaboration (as well as through the type and number of collaborators), seems an essential information for a manager in order to optimize his R\&D project portfolio.

\section{METHODOLOGICAL APPROACH AND ESTIMATION STRATEGY} Input additionality analysis

In the first step of our analysis, we are interested in estimating the treatment effect of the R\&D subsidy on firms' R\&D investments. As subsidies are not randomly distributed, one has 
to take the selection into the funding program into account in the evaluation analysis. Indeed, subsidized firms might differ from non-subsidized firms in important characteristics, and therefore the selection into the treatment has to be taken into account (Heckman, LaLonde, \& Smith, 1999; Imbens \& Wooldridge, 2008). While several modern econometric techniques exist allowing to address such a selection bias, our study applies a non-parametric propensity score matching (Angrist, 1998; Gerfin \& Lechner, 2002; Lechner, 1999; Smith \& Todd, 2005). The econometric matching allows to directly reply to the question of how much a subsidized firm would have invested in $\mathrm{R} \& \mathrm{D}$ if it would be in a counterfactual situation of not having received public support. Compared to other methods such as the difference-indifference estimator or selection models, the econometric matching requires neither panel data nor imposes functional form assumptions. For the data at hand (to be described in detail in the next section), this thus seems the most adequate estimation approach.

Given that this counterfactual situation of how much a subsidized firm would have invested in $R \& D$ if it would not have received a subsidy is never observable, it has to be estimated. Based on the assumption that we observe all the important characteristics driving the selection into the treatment (that is, provided that the conditional independence assumption (CIA) is respected (Rubin, 1977)), we can approximate this counterfactual situation by firms having the same (or very similar) characteristics than the subsidized firms, but have not received any support. In order to find such similar "twins", we balance the subsamples of subsidized and non-subsidized firms according to the probability of receiving a subsidy. Put differently, based on a probit estimation, we obtain the conditional probability of receiving a subsidy in a single index, the propensity score. Based on this index, we apply a nearest neighbour matching estimation and use for each subsidized firm the single nearest neighbour to estimate the counterfactual situation (Dehejia \& Wahba, 2002; Rosenbaum \& Rubin, 
1985). On top of matching on the propensity score, we further require firms of the treated and control groups to belong to the same year and the same industry.

The average treatment effect on the treated is estimated as follows:

$$
\alpha_{A T T}=\frac{1}{N^{T}} \sum_{i=1}^{N^{T}}\left(R \& D_{i}^{T}-\widehat{R \& D_{i}^{c}}\right)
$$

where $R \& D_{i}^{T}$ indicates $\mathrm{R} \& \mathrm{D}$ expenditures of treated firms and $\widehat{R \& D}_{i}^{c}$ the counterfactual situation, i.e. the potential outcome which would have been realized if the treatment group $(S=1)$ had not been treated. $S \in\{0,1\}$ indicates the receipt of a subsidy and $N^{T}$ the number of treated firms.

Finally, in order for the matching to be possible, enough common support is needed between the sample of treated firms and the sample of potential control firms. In other words, the samples of treated and control firms need to have enough overlap in terms of probability of receiving a subsidy. We thus delete observations on treated firms with probabilities larger than the maximum and smaller than the minimum of the potential control group.

\section{Effectiveness of the $R \& D$ policy}

In a second part, we turn to the analysis of how the additional policy-induced $R \& D$ investment translates into innovation performance. More precisely, provided that we find positive input additionality, we want to know whether the publicly induced R\&D investment impacts radical or incremental innovations (or both).

Taking into account that not every firm in our sample has new product sales in each period, our outcome measures are characterized by a corner solution around zero (Tobin, 1958). For our analysis, we therefore use Tobit models to give point to these censored dependent variables. 
In order to disentangle public form private $R \& D$ investment, we estimate the policy impact at the firm level in the same fashion as Hottenrott and Lopes-Bento (2014a) as follows:

$\alpha_{i}^{T T}=R \& D_{i}-\widehat{R \& D}^{C}$

where $\widehat{R \& D}^{C}$ is equal to $\mathrm{R} \& \mathrm{D}$ intensity for the counterfactual firms. Indeed, for nonsubsidized firms, for which $\alpha_{i}^{T T}$ is equal to zero, $\widehat{R \& D}^{C}{ }_{i}$ corresponds to their private $\mathrm{R} \& \mathrm{D}$ investment.

The tobit model for Radical ${ }_{i}$ can then be estimated as follows:

$\operatorname{Radical}^{*}{ }_{i}=X^{\prime}{ }_{i} \beta+\epsilon_{i}, \epsilon_{i} \sim$ i. i.d. $N\left(0, \sigma^{2}\right)$

Radical $_{i}=\left\{\begin{array}{c}\text { Radical }_{i}^{*} \text { if } X^{\prime} \beta+\epsilon_{i}>0 \\ 0 \text { otherwise }\end{array}\right.$

where Radical $_{i}$ is the non-negative observable innovation performance variable, capturing radical innovation at the firm level. Radical $_{i}$ corresponds to the latent dependent variable Radical $_{i}{ }_{i}$ if latter is above zero, and to zero otherwise. The model on the latent dependent variable, Radical $^{*}{ }_{i}$ is estimated by a parameter vector $\beta$, and a vector of firm characteristics $X_{i}$. The latter relationship is affected by a normally distributed error, to capture randomized firm influences. The model on incremental innovation is estimated analogously.

In order for the estimates of a Tobit estimation to be consistent (see Wooldridge, 2010, pp. 680-687), homoscedasticity is required. Given that we found evidence for heteroscedasticity based on an Likelihood Ratio test, we estimate heteroscedastic robust tobit models by maximum likelihood. Therefore, we replace the homoscedastic standard error term $\sigma$ with $\sigma_{i}$ $=\sigma \exp \left(Z^{\prime} \alpha\right)$ in the likelihood function, modeling for group-wise multiplicative heteroscedasticity by including firm size and industry dummies. Accounting the fact that our 
estimates for $\mathrm{R} \& \mathrm{D}$ investments $\left(\alpha_{i}^{T T}, \widehat{R \& D}^{C}\right)$ are estimated values for the treated firms, ordinary standard errors would be biased. We thus correct our standard errors by conducting a bootstrapping procedure. ${ }^{4}$

\section{DATA AND MODEL SPECIFICATION}

Data

For the empirical analysis, the study uses a large-scale sample firms, derived from five waves (1999, 2002, 2005, 2008, and 2011) of the Swiss innovation survey. The Swiss innovation survey is a postal survey conducted by the KOF Swiss Economic Institute at the ETH Zurich, and corresponds largely to the European Community Innovation Survey following the OECD guidelines (OECD, 1992). Our data set provides us with a representative sample, covering both manufacturing and service industries. The data set contains detailed information on firms' R\&D and innovation activities, performance measures, subsidy receipts, and other firm characteristics. The response rates from the surveys are: $33.8 \%$ (1999), 39.6\% (2002), 38.7\% (2005), 36.1\% (2008), and 35.9\% (2011). After eliminating missing values, and limiting our sample to innovating firms only, we are left with 6084 observations from 3552 different firms out of which 546 received a subsidy.

\section{Dependent variables}

Our analysis is separated into two main parts. For the treatment effects analysis, our outcome variable reflects the firms' $R \& D$ investment measured as the $R \& D$ expenditures to total turnover (RDINT). In the second part, our outcome variables indicate radical innovation performance $(R A D I C A L)$, measured as the sales share of radical innovative products-which are products new to the market or new to the firm, and incremental innovation performance (INCREMENTAL), measured as the sales share of significantly improved products. ${ }^{5}$ 


\section{Main explanatory variables}

The receipt of a subsidy is indicated by a dummy (PUBSUB) equal to one for subsidized firms and zero otherwise. Privately invested R\&D expenditures and publicly induced expenditure are denoted by $\widehat{R \& D}^{C}$ and $\alpha_{i}^{T T}$ respectively.

As an important part of our setting is to analyse the role of collaboration pattern, we account for various collaboration partners as well as the number of collaboration partners by including several variables to capture different collaboration constellations. A dummy $(R D C O O P)$ simply indicates if a firm is engaged in $\mathrm{R} \& \mathrm{D}$ collaboration. Taking into account the effects of increased collaboration engagement, we define a continuous variable (COOPPART) accounting for different external collaborating partners (suppliers, clients, competitors, non-competitors, firms from the same corporate group, universities, and other research institutions). Following Belderbos et al. (2004b) we further distinguish between vertical (CO_VERT), horizontal collaboration $\left(C O \_H O R\right)$, and collaboration with science (CO_SCIE).

\section{Other control variables}

We further control for a set of variables which might influence the selection into public funding and/or drive innovation performance.

Having received a subsidy in the past might demonstrate existing competence and capabilities of the applicant and hence might influence the agency to select this firm again for a grant. We thus control for previous subsidies, where PAST_SUBSIDY equals one if a firm has received a subsidy in the past three years. Existing $R \& D$ capabilities may also be reflected in existing patents at the firm level. Indeed, patents may be a valid signal of previously successful $R \& D$ engagement. Consequently, we include a variable (PAT_EMPL) measuring successfully 
approved patents per 1,000 employees to avoid potential multicollinearity with firm size. We further control for firm age (FIRMAGE) and (the log of) firm size (LNFIRMSIZE), as these are important characteristics in the funding scheme of the agency. Additionally, we take a non-linear relationship into account and control for the squared term of the two previously mentioned variables (FIRMAGE2, LNFIRMSIZE2). Labour productivity might also influence the agency in the approval process, as it can be seen as an indicator for high firm competitiveness. We include the natural logarithm of the sales share per employee (LNLABPROD). As stated by Cohen and Levinthal (1990), absorptive capacity is essential to integrate new knowledge. We therefore control for share of workforce with tertiary education in total employment (EMPACA). We further control for the fact that a firm belongs to a foreign group (FOREIGN). Subsidiaries with a foreign parent may be less likely to receive subsidies, because the parent may prefer to apply in its home country. Likewise, funding agencies may have a preference for local firms. Furthermore, foreign parents with local subsidiaries are typically larger firms and may therefore not be the priority target of the funding agency as SMEs generally constitute the main target group. It could, however, also be that firms belonging to a group may look attractive to a funding agency as the group membership possibly promises knowledge spillovers and thus economies of scope from the $\mathrm{R} \& \mathrm{D}$ process that go beyond national borders. It is thus unclear whether having a foreign parent plays favourably or not in receiving a subsidy from a Swiss funding agency. We take foreign market activities of a firm into account by controlling for its export activities. Highly export orientated firms might be more innovative, and hence more likely to apply for a subsidy. Export activities are measured by the export share to total turnover (EXPORT). In addition, we account for the level of general technological potential of a firm (TECHPOT) indicating the level of scientific and technological knowledge available to the firm for conducting innovation activities. TECHPOT is measured on a five point Likert-scale, where 
five indicates a high technological potential of the focal firm. Finally, five survey year dummies and seven industry sector dummies complement our set of control variables.

\section{Descriptive statistics}

Table 1 presents descriptive statistics of the variables in our analysis; industry and size class distribution of our sample are displayed in Table A.1 and A.2 in the appendix. As presented in Table 1, there exist significant differences in the means of almost all variables between the subsidized firms and the non-subsidized firms. For instance, on average, subsidized firms are more likely to have experience in the past with subsidies, are slightly larger, have more approved patents per employee, have a higher likelihood belonging to a foreign group, have a higher educated workforce, are more export-oriented, have a higher technological potential, and engage more in R\&D collaboration. Notably, they do not differ in firm age, and labour productivity. With respect to the outcome variable, in alignment with our expectation, subsidized firms have on average higher R\&D investments. However, at this point, we do not know how much of these additional R\&D expenditures are induced by the subsidy or are due to other firm characteristics. 
Table 1 Descriptive statistics on innovating firms.

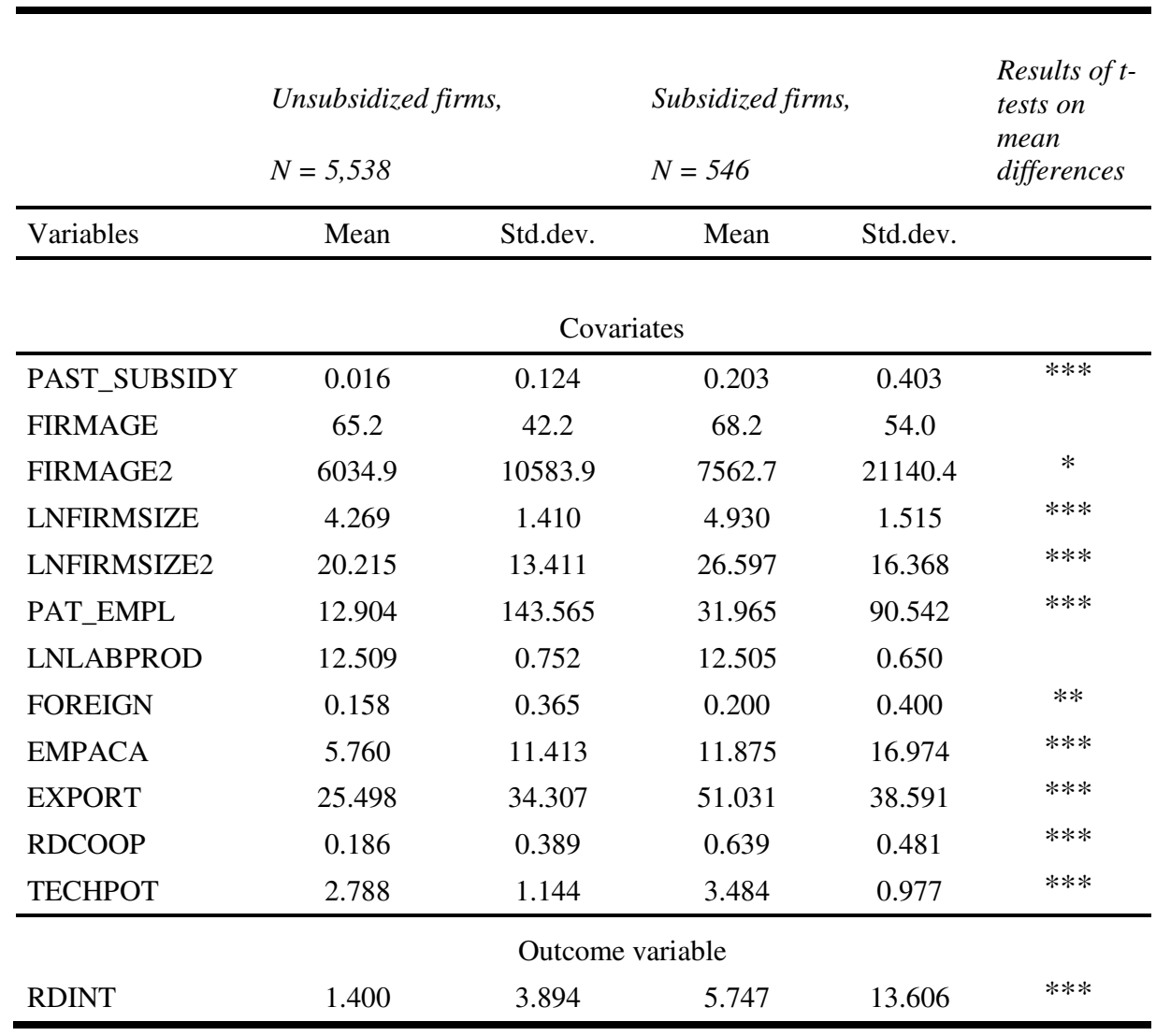

Source: Own calculations. Data derived from the Innovation survey conducted by the Swiss Economic Institute (KOF).

\section{EMPIRICAL ANALYSIS AND DISCUSSION}

Average effect of public funding on subsidized firms

As described above, we employ a matching estimation to identify the average treatment effect of public R\&D grants on the treated firms. To be able to apply the matching estimator, we need to predict the probability of receiving public $R \& D$ funding. Therefore, we estimate a probit model on a subsidy receipt incorporating important characteristics for the selection into the funding scheme. As can be seen in Table 2, with the exception of firm age, patents per employee, and being member of a foreign group, all our covariates are important drivers for the selection into the treatment. 
Table 2 Probit estimation on the probability of receiving a subsidy.

\begin{tabular}{|c|c|c|}
\hline Variables & Coefficient & Standard errors \\
\hline PAST_SUBSIDY & $1.149 * * *$ & $(0.100)$ \\
\hline FIRMAGE & -0.001 & $(0.000)$ \\
\hline FIRMAGE2 & 0.000 & $(0.000)$ \\
\hline LNFIRMSIZE & $0.142 *$ & $(0.090)$ \\
\hline LNFIRMSIZE2 & -0.004 & $(0.010)$ \\
\hline PAT_EMPL & 0.000 & $(0.000)$ \\
\hline LNLABPROD & $-0.217 * * *$ & $(0.040)$ \\
\hline FOREIGN & -0.082 & $(0.070)$ \\
\hline EMPACA & $0.013 * * *$ & $(0.000)$ \\
\hline EXPORT & $0.004 * * *$ & $(0.000)$ \\
\hline RDCOOP & $0.770 * * *$ & $(0.060)$ \\
\hline TECHPOT & $0.148 * * *$ & $(0.030)$ \\
\hline $\mathrm{N}$ & 6084 & \\
\hline Log likelihood & -1392.4211 & \\
\hline $\begin{array}{l}\text { Joint significance of industry } \\
\text { dummies }\end{array}$ & $\chi 2(6)=19.92 * * *$ & \\
\hline $\begin{array}{l}\text { Joint significance of survey year } \\
\text { dummies }\end{array}$ & $\chi 2(4)=27.01 * * *$ & \\
\hline
\end{tabular}

Table 3 presents the results of our econometric matching estimation. We can see that all our covariates are well-balanced after the matching. This points to the fact that our matching was successful and that we found a close neighbour for each of our treated firms. The only variable that remains statistically significant is the outcome variable. We can thus attribute this difference to the treatment and can conclude that, in line with the literature, full crowding out can be rejected.

In order to take a potential selection on unobservables into account, we test the robustness of our matching estimation by conducting an IV regression. The results of the IV regression as well as the choice of our IVs are presented in detail Appendix 2 (Table A.4). Conclusions remain unchanged even if we allow for a selection on unobservables. 
Table 3 Average treatment effect of public R\&D funding.

\begin{tabular}{|c|c|c|c|c|c|}
\hline & \multicolumn{2}{|c|}{ Selected control group, $N=530$} & \multicolumn{2}{|c|}{ Subsidized firms, $N=530$} & \multirow[t]{2}{*}{$\begin{array}{l}p \text {-value of } t \text {-tests } \\
\text { on mean } \\
\text { differences }\end{array}$} \\
\hline Variables & Mean & Std.dev. & Mean & Std.dev. & \\
\hline \multicolumn{6}{|c|}{ Covariates } \\
\hline PAST_SUBSIDY & 0.145 & 0.353 & 0.179 & 0.384 & 0.195 \\
\hline FIRMAGE & 69.8 & 47.2 & 68.4 & 54.1 & 0.707 \\
\hline FIRMAGE2 & 7097.0 & 11617.0 & 7605.1 & 21382.6 & 0.656 \\
\hline LNFIRMSIZE & 4.765 & 1.452 & 4.891 & 1.485 & 0.234 \\
\hline LNFIRMSIZE2 & 24.815 & 14.577 & 26.120 & 15.855 & 0.228 \\
\hline PAT_EMPL & 20.623 & 54.565 & 28.963 & 79.044 & 0.072 \\
\hline LNLABPROD & 12.483 & 0.668 & 12.496 & 0.648 & 0.784 \\
\hline FOREIGN & 0.183 & 0.387 & 0.198 & 0.399 & 0.591 \\
\hline EMPACA & 12.578 & 19.054 & 11.259 & 16.303 & 0.311 \\
\hline EXPORT & 49.026 & 38.315 & 50.302 & 38.537 & 0.644 \\
\hline RDCOOP & 0.632 & 0.483 & 0.628 & 0.484 & 0.913 \\
\hline TECHPOT & 3.453 & 1.015 & 3.457 & 0.974 & 0.958 \\
\hline \multicolumn{6}{|c|}{ Outcome variables } \\
\hline RDINT & 3.453 & 5.859 & 5.698 & 13.717 & 0.001 \\
\hline
\end{tabular}

Note: Own calculations. Data derived from the Innovation survey conducted by the Swiss Economic Institute $(\mathrm{KOF}) . * * *(* *, *)$ indicate a significance level of $1 \%(5 \%, 10 \%) .16$ observations are lost because of the common support condition.

\section{Impact of firm collaboration patterns on the estimated treatment effect}

Even though collaboration is not a full requirement to receive a subsidy, the funding agency encourages collaboration engagement of the applicant firms. We are therefore interested in knowing whether (and to which extent) the created additionality is impacted by specific collaboration patterns. In order to identify the effect of collaboration, we run three different OLS regressions, regressing the individual treatment effect on the previously defined collaboration variables. The results are presented in Table 4. The result in Model 1, where we regress the additionality created by a subsidy on a dummy variable equal to one if a firm is an R\&D collaborator, shows no statistical significant impact. In Model 2, we therefore control for the diversity of collaboration partners $(C O O P P A R T \in[1,7])$ rather than a mere dummy. 
Surprisingly, we detect a negative significant effect of increased collaboration engagement on the treatment effect. I.e. having more than one collaboration partner at the same time has a negative impact of subsidy additionality. When differentiating between the types of collaboration partner (Model 3), our results show that the negative effects are driven by collaboration with suppliers, while collaboration with other partners has no impact on additionality. ${ }^{6}$

The fact that collaboration exhibits a negative impact seems rather surprising, given that typically positive impacts of $R \& D$ collaboration on $R \& D$ activities are found. As we mentioned in the previous paragraph however, collaboration is also linked to a number of costs. In terms of created additionality, it seems that the costs outweigh the benefits for the firms in our sample. In the next section we will analyze how specific collaboration patterns influence product novelty sales, due to private investment as well as due to policy induced investment, which will enable us to conclude if collaborative research impacts input and output differently. 
Table 4 OLS regression models on the individual treatment effect, $\boldsymbol{\alpha}_{i}^{T \boldsymbol{T}}$, taking into account the collaboration pattern of the subsidized firms, $\mathrm{N}=530$.

\begin{tabular}{|c|c|c|c|}
\hline & Model 1 & Model 2 & Model 3 \\
\hline \multirow[t]{2}{*}{ RDCOOP } & -3.294 & & \\
\hline & $(2.00)$ & & \\
\hline \multirow[t]{2}{*}{ COOPPART } & & $-0.914 * * *$ & \\
\hline & & $(0.34)$ & \\
\hline \multirow[t]{2}{*}{ Cooperation with CUSTOMERS } & & & 1.064 \\
\hline & & & $(2.06)$ \\
\hline \multirow[t]{2}{*}{...SUPPLIERS } & & & $-5.192 * * *$ \\
\hline & & & $(1.91)$ \\
\hline \multirow[t]{2}{*}{...COMPETITORS } & & & -1.015 \\
\hline & & & $(1.47)$ \\
\hline \multicolumn{4}{|l|}{...FIRMS FROM OTHER } \\
\hline \multirow[t]{2}{*}{ INDUSTRIES } & & & -1.318 \\
\hline & & & $(1.44)$ \\
\hline \multicolumn{4}{|l|}{... FIRMS FROM THE SAME } \\
\hline \multirow[t]{2}{*}{ COMPANY GROUP } & & & 0.684 \\
\hline & & & $(2.11)$ \\
\hline \multirow[t]{2}{*}{...UNIVERSITIES } & & & 1.079 \\
\hline & & & $(2.48)$ \\
\hline \multirow[t]{2}{*}{...OTHER RESEARCH ENTITIES } & & & -1.791 \\
\hline & & & $(1.76)$ \\
\hline \multirow[t]{2}{*}{ Intercept } & $4.315^{* *}$ & $4.347 * * *$ & $4.098 * * *$ \\
\hline & $(1.78)$ & $(1.50)$ & $(1.56)$ \\
\hline \multirow[t]{2}{*}{ Number of observations } & 530 & 530 & 530 \\
\hline & $\mathrm{F}(1,409)=2.71$ & $\mathrm{~F}(1,409)=7.14$ & $F(7,409)=2.12$ \\
\hline Overall significance & Prob $>F=0.100$ & Prob $>F=0.008$ & Prob $>F=0.040$ \\
\hline
\end{tabular}

Source: Own calculations. Data derived from the Innovation survey conducted by the Swiss Economic Institute (KOF). Note: Standard errors are clustered at the firm level, as some firms appear more than once in the sample. $* * *(* *, *)$ indicate a significance level of $1 \%(5 \%, 10 \%)$.

\section{The impact on innovation performance}

In the following section, we turn to the analysis on innovation performance, as measured by the sales share of radically and incrementally new products respectively. The average sales share from radically new products is of $14.4 \%$ in our sample. Incremental innovations account for $16.7 \%$ of the total turnover of the firms in our sample. 
Table 5 displays the results of the heteroscedasticity-robust Tobit models on innovation outcome. Models one to four relate to the impact of the both types of R\&D investment on radical innovation, while models five to eight relate to incremental innovation. The various models per category take into account different collaboration patterns.

All models exhibit a positive impact of privately invested $\mathrm{R} \& \mathrm{D}, \widehat{R \& D}^{C}$, on the sales share of new products, radical or incremental alike. When considering the baseline models (Model 1 and Model 5), we see that the coefficients are similar in size, pointing to the fact that the impact of the counterfactual $R \& D$ investment is not significantly different between both types of innovation. Put differently, the private money invested by firms displays a significant impact on incremental as well as on radical innovation which is similar in magnitude. A $10 \%$ increase in the counterfactual R\&D investment would lead to a 4 percentage point increase in the estimated latent dependent variable, i.e. the estimated sales share in radical innovation sales, on average, and a 3 percentage point increase in the estimated sales share for incremental innovation sales.

While this finding is in line with our expectations, the effects related to the publicly induced R\&D investment, $\alpha_{i}^{T T}$, strive our attention. The results show a positive and statistically significant effect of the publicly induced R\&D investment on radical innovation (Model 1), while the effect on incremental innovation is insignificant (Model 5). Even though officially the funding agency also supports projects with short- and medium-term marketable goals, this finding points to the fact that the publicly induced part of the $R \& D$ investment mainly impacts radical innovation. Hence the goal of the agency to promote more basic and radical innovation seems to be attained. The impact of public support is highest where market failures are highest. 
Given that the funding agency typically favours R\&D collaborating firms, we are interested in knowing if these effects are impacted by collaboration behaviour. Since the mere dummy variable on collaboration did not display any significant impact on input additionality, we control for the number of different collaboration partners in our innovation performance equation (COOPPART) in the baseline models (Models 1 and 5). As we can gather from Table 5, significant results are only found for incremental innovation (Model 5). Indeed, we find that engaging into collaboration agreements with different partners induces, on average, an increase in the estimated sales share from incremental product novelties of roughly 8 percentage points (Model 5).

Going forward, we differentiate between the types of external collaboration partners, differentiating between horizontal, vertical and diagonal ${ }^{7}$. The analysis shows that neither one of the collaboration types has a significant impact when controlled for separately (see Models 2 and 6). Finally, to see whether these effects change in light of the receipt of a subsidy, we interact privately as well as publicly induced R\&D investment with collaboration patterns. Models 3 and 7 start by interacting partner diversity with both types of R\&D investment. For incremental innovations (Model 7), we see that while the counterfactual R\&D spending and collaborating with diverse partners stays significant and positive, the part of the private spending that is interacted with collaborators exhibits a negative impact. Hence, parts of the positive impact of private $R \& D$ spending turns negative when driven by collaboration with various partners. In line with the results from the baseline model, no statistically significant results are found for radical innovation output.

Disentangling the types of collaboration by partner type, our results indicate that these negative effects are driven by collaboration with science for privately invested $R \& D$ on incremental innovation (Model 8), while in terms of policy-induced R\&D investment, a 
negative relation is found with horizontal collaboration. Consistent with previous results, no significant impacts are found for radical innovation (Model 4).

While the results of Models 7 and 8 seem surprising, there may be several reasons able to explain such findings. Firstly, the negative effects of having several collaboration partners at the same time may be due to the fact that the costs of coordination and managing a (subsidized) partnership can be very high (see Hottenrott and Lopes-Bento, 2014). Secondly, when disentangling the type of collaboration, we see that the interaction between privately invested $R \& D$ and collaboration with science is negative. This may be due to the fact that collaboration with science is typically needed when firms intend doing path-breaking innovations, pushing the technological frontier. For incremental innovation, such type of collaboration is therefore not necessarily attractive, and may deviate resources from where they could have been invested more appropriately in terms of incremental change to existing products. Hence, if the strategy of the firm is to ensure long-term survival perspectives through incremental innovation rather than investing into radical innovation, it seems that collaborating with science is not maximizing its partnership behaviour.

In terms of policy effect in light of collaboration type, our results do not show any evidence that subsidized collaborating firms are more productive in terms of new products than nonsubsidized firms. To the contrary, we even find a weak, yet negative results for the interaction of policy driven investment and horizontal collaboration.

Before concluding, it should be noted that we took potential endogeneity of our collaboration variables into account. In Appendix 3, we estimate a structural equation as introduced by Blundell and Smith (1986) to see if our results are driven by endogenetiy. As shown by the results in Table A.5, our findings are not driven by endogeneity. ${ }^{8}$ 
Table 5 Heteroscedasticity-robust Tobit estimates on radical and incremental innovation performance.

\begin{tabular}{|c|c|c|c|c|c|c|c|c|}
\hline \multirow[b]{2}{*}{ Variables } & \multicolumn{4}{|c|}{$R A D I C A L$} & \multicolumn{4}{|c|}{ INCREMENTAL } \\
\hline & Model 1 & Model 2 & Model 3 & Model 4 & Model 5 & Model 6 & Model 7 & Model 8 \\
\hline$\alpha_{i}^{\mathrm{TT}}$ & $\begin{array}{c}0.370^{* *} \\
(0.15)\end{array}$ & $\begin{array}{c}0.366^{* * *} \\
(0.15)\end{array}$ & $\begin{array}{l}0.248 \\
(0.31)\end{array}$ & $\begin{array}{l}0.237 \\
(0.36)\end{array}$ & $\begin{array}{l}0.518 \\
(0.35)\end{array}$ & $\begin{array}{l}0.526 \\
(0.36)\end{array}$ & $\begin{array}{l}0.402 \\
(0.39)\end{array}$ & $\begin{array}{l}0.289 \\
(0.38)\end{array}$ \\
\hline$\widehat{\mathrm{R} \& \mathrm{D}}^{\mathrm{C}}$ & $\begin{array}{c}0.434 * * * \\
(0.12)\end{array}$ & $\begin{array}{c}0.428 * * * \\
(0.12)\end{array}$ & $\begin{array}{c}0.431 * * * \\
(0.16)\end{array}$ & $\begin{array}{c}0.548 * * * \\
(0.16)\end{array}$ & $\begin{array}{c}0.319 * * \\
(0.16)\end{array}$ & $\begin{array}{c}0.332 * * \\
(0.15)\end{array}$ & $\begin{array}{c}0.726 * * * \\
(0.19)\end{array}$ & $\begin{array}{c}0.770 * * * \\
(0.21)\end{array}$ \\
\hline COOPPART & $\begin{array}{l}0.157 \\
(0.19)\end{array}$ & & $\begin{array}{l}0.128 \\
(0.22)\end{array}$ & & $\begin{array}{c}0.787 * * * \\
(0.27)\end{array}$ & & $\begin{array}{c}1.272 * * * \\
(0.40)\end{array}$ & \\
\hline FIRMAGE & $\begin{array}{c}-0.064 * * * \\
(0.02)\end{array}$ & $\begin{array}{c}-0.064 * * * \\
(0.02)\end{array}$ & $\begin{array}{c}-0.064 * * * \\
(0.02)\end{array}$ & $\begin{array}{c}-0.063 * * * \\
(0.02)\end{array}$ & $\begin{array}{c}-0.123 * * * \\
(0.05)\end{array}$ & $\begin{array}{c}-0.121 * * * \\
(0.05)\end{array}$ & $\begin{array}{c}-0.122 * * * \\
(0.05)\end{array}$ & $\begin{array}{c}-0.118 * * * \\
(0.05)\end{array}$ \\
\hline FIRMAGE2 & $\begin{array}{c}0.000 * * \\
(0.00)\end{array}$ & $\begin{array}{c}0.000 * * \\
(0.00)\end{array}$ & $\begin{array}{c}0.000^{* *} \\
(0.00)\end{array}$ & $\begin{array}{c}0.000 * * \\
(0.00)\end{array}$ & $\begin{array}{c}0.000 * * \\
(0.00)\end{array}$ & $\begin{array}{c}0.000 * * \\
(0.00)\end{array}$ & $\begin{array}{c}0.000 * * \\
(0.00)\end{array}$ & $\begin{array}{c}0.000 * * \\
(0.00)\end{array}$ \\
\hline LNFIRMSIZE & $\begin{array}{l}0.924 \\
(0.92)\end{array}$ & $\begin{array}{l}0.934 \\
(0.92)\end{array}$ & $\begin{array}{l}0.969 \\
(0.94)\end{array}$ & $\begin{array}{l}1.018 \\
(0.97)\end{array}$ & $\begin{array}{l}-0.714 \\
(1.16)\end{array}$ & $\begin{array}{l}-0.739 \\
(1.15)\end{array}$ & $\begin{array}{l}-0.763 \\
(1.15)\end{array}$ & $\begin{array}{l}-0.627 \\
(1.12)\end{array}$ \\
\hline LNFIRMSIZE2 & $\begin{array}{l}-0.103 \\
(0.09)\end{array}$ & $\begin{array}{l}-0.104 \\
(0.09)\end{array}$ & $\begin{array}{l}-0.107 \\
(0.10)\end{array}$ & $\begin{array}{l}-0.111 \\
(0.10)\end{array}$ & $\begin{array}{l}0.074 \\
(0.11)\end{array}$ & $\begin{array}{l}0.087 \\
(0.11)\end{array}$ & $\begin{array}{l}0.082 \\
(0.11)\end{array}$ & $\begin{array}{l}0.081 \\
(0.11)\end{array}$ \\
\hline EXPORT & $\begin{array}{c}0.052 * * * \\
(0.02)\end{array}$ & $\begin{array}{c}0.052^{* * *} \\
(0.01)\end{array}$ & $\begin{array}{c}0.052 * * * \\
(0.02)\end{array}$ & $\begin{array}{c}0.052 * * * \\
(0.01)\end{array}$ & $\begin{array}{c}0.039 * * * \\
(0.01)\end{array}$ & $\begin{array}{c}0.044 * * * \\
(0.01)\end{array}$ & $\begin{array}{c}0.037 * * * \\
(0.01)\end{array}$ & $\begin{array}{c}0.043 * * * \\
(0.01)\end{array}$ \\
\hline TECHPOT & $\begin{array}{c}1.353 * * * \\
(0.44)\end{array}$ & $\begin{array}{c}1.336 * * * \\
(0.46)\end{array}$ & $\begin{array}{c}1.359 * * * \\
(0.43)\end{array}$ & $\begin{array}{c}1.276^{* * * *} \\
(0.50)\end{array}$ & $\begin{array}{c}1.932 * * * \\
(2.93)\end{array}$ & $\begin{array}{c}2.006 * * * \\
(0.39)\end{array}$ & $\begin{array}{c}1.831 * * * \\
(0.43)\end{array}$ & $\begin{array}{c}1.838 * * * \\
(0.43)\end{array}$ \\
\hline
\end{tabular}




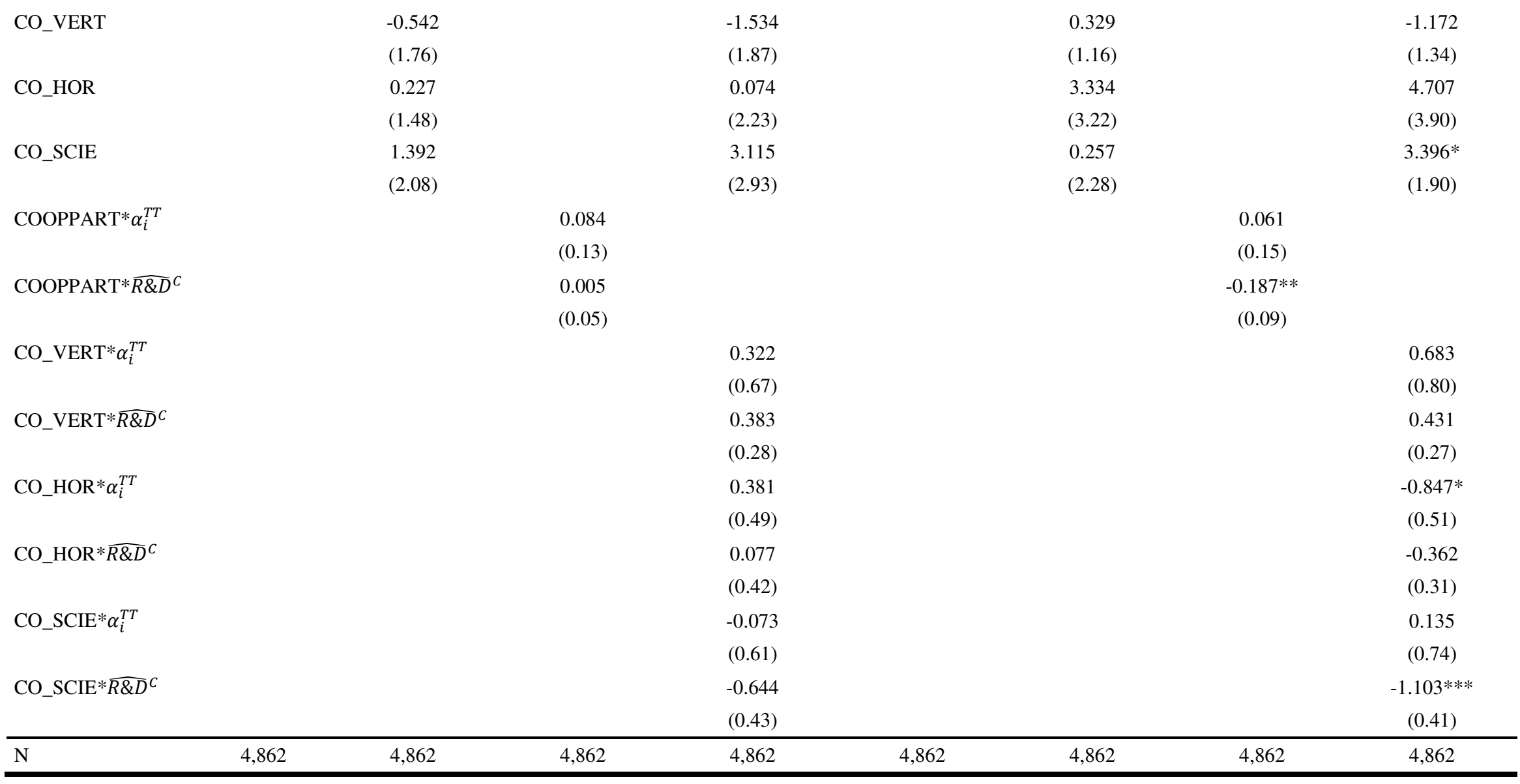

Source: Own calculations. Data derived from the Innovation survey conducted by the Swiss Economic Institute (KOF). Note: Standard deviations in parentheses are

clustered at the firm level and bootstrapped with 150 replications. Time and industry dummies are jointly significant (not presented). $* * *(* *, *)$ indicate a significance level of $1 \%(5 \%, 10 \%)$. 


\section{CONCLUSION}

Our study is an extension of previous studies interested in the effects of public R\&D polices on input and/or output additionality. Indeed, we contribute to current knowledge on the effect of such policy by providing evidence as to where the policy impact is highest. Furthermore, we take specific collaboration patterns into account to see whether these impacts are affected by the number or the type of partnering firms.

In terms of input additionality, we find, in line with previous studies, evidence that allows rejecting the null hypothesis of full crowding out.

Taking into account the degree of novelty in terms of innovation performance, this analysis fills a gap by providing evidence on where the policy effect hits most: on innovations close to the market (incremental innovations) or on innovations far from the market (radical innovations). Using data from the Swiss Innovation Survey, we find evidence that publicly induced investments display a positive and significant impact on radical innovation, while no significant impact on incremental innovation is found. This points to the fact that the policy effect does impact the firm where, left to itself, the constraints would have been highest.

Given that funding policy often encourage firms to collaborate in their R\&D activities, our work integrates information on firms' collaboration status. Compared to previous studies that only consider whether or not a firm qualifies as collaborator, we additionally account for specific types (and the number) of collaboration partners. We are thus able to investigate the effects of different collaboration constellations, i.e. horizontal, vertical and collaboration with science in our framework. We do not find any evidence that subsidized collaborating firms exhibit higher input additionality. To the contrary, having several partners simultaneoulsy even lowers the impact. While the type (and number) of collaboration partners does not display a significant impact on the sales share of radical innovation, it impacts incremental 
innovation. Once interacted with policy effects, these impacts turn negative. Hence, the policy effect is not enhanced by a specific collaboration strategy and collaborative R\&D should thus not necessarily constitute a priority for the Swiss funding agency.

Combing strategic management literature on radical vs incremental innovation and on collaboration impacts with literature on policy evaluation, our study also allows drawing implications from a managerial perspective. From a managerial point of view, the findings are relevant from mainly two angles. In terms of subsidy strategy, it is vital for a manager to know that it is more likely for a subsidy to have the desired impact when used for more radical innovation projects. From a collaboration strategy perspective, it is important to know that there are also downsides to engaging into collaboration, especially with a number of diversified partners. Hence, if tempted to engage in additional R\&D collaborations in order to increase the probability of receiving a subsidy, managers should be aware that there may also be downsides to this strategy.

Despite all efforts, our analysis is not without limitation. One clear improvement would be to have access to panel data, allowing to follow firms over time. Furthermore, having more information about the selection process or about the rejected applicants would have allowed for a series of additional robustness checks to strengthen our findings. 


\section{Appendices}

\section{Appendix 1}

Table A.1 Descriptive statistics, industry distribution.

\begin{tabular}{|c|c|c|}
\hline Industry & Number of firms & Percentages \\
\hline 1 Construction, mining, energy & 441 & 7.25 \\
\hline 2 Consumer goods (food, beverages, tobacco, textiles, clothing) & 433 & 7.12 \\
\hline $\begin{array}{l}3 \text { Intermediate goods (paper, printing, chemicals, } \\
\text { pharmaceuticals, rubber, plastics, minerals, basic metals) }\end{array}$ & 1,051 & 17.27 \\
\hline $\begin{array}{l}4 \text { Investment goods (fabricated metals, machinery \& equipment, } \\
\text { electrical equipment, electronics and optical products, medical } \\
\text { instruments, watches, vehicles, and other manufacturing) }\end{array}$ & 2,111 & 34.7 \\
\hline $\begin{array}{l}5 \text { Traditional services (trade, transportation, } \\
\text { telecommunications) }\end{array}$ & 923 & 15.17 \\
\hline $\begin{array}{l}6 \text { Knowledge-based services (banking, insurance, information } \\
\text { technology \& services, technical commercial services) }\end{array}$ & 874 & 14.37 \\
\hline 7 Other services & 251 & 4.13 \\
\hline Total & 6,084 & 100 \\
\hline
\end{tabular}

Table A.2 Descriptive statistics, firm size distribution.

\begin{tabular}{llll}
\hline Size class & Size class distribution & Number of firms & Percentages \\
\hline 1 Small-sized firms & $1-49$ & 2,489 & 40.91 \\
2 Medium-sized & $50-249$ & 2,405 & 39.53 \\
3 Large-sized & $250-$ max. & 1,190 & 19.56 \\
\hline & Total & $\mathbf{6 , 0 8 4}$ & $\mathbf{1 0 0}$ \\
\hline
\end{tabular}




\section{Appendix 2}

\section{Robustness check for the matching estimation accounting for potential selection on unobservables}

An essential assumption to conduct a valid matching estimation is the conditional independence assumption (CIA). Indeed, for the matching estimation to be valid, the outcome has to be statistically independent of program participation, conditional on a series of observable characteristics. This fundamental assumption is however not testable. Therefore, we test the robustness of our matching estimation results by taking into account the selection on observables. We do so using an instrumental variables (IV) approach.

To conduct our IV regression, we employ two instruments for the subsidy receipt. First, we use the likelihood of receiving a subsidy by region and industry (IV_1); and second, we use the likelihood of collaborating with science by industry (IV_2).

IV_1 is justified by the fact that funding agencies often have preferences in terms of location or industries. Even though such priorities are not formal conditions, it may very well be that a firm based in direct proximity of a funding agency is more aware of the policy and is more visible to the decision makers than a firm that is situated further away. Hence, being part of a region or an industry where the likelihood of receiving a subsidy is high, is likely to impact the receipt of a subsidy of firm $\mathrm{i}$. The rationale of using the industry average of collaboration with science institutions as an instrument (IV_2) documents the fact that some technological trajectories have closer relationships to universities and other research centres. Having a closer relationship to science collaboration increases the likelihood of being retained for funding, given that the Swiss government aims at increasing industry - science links.

Both instruments fulfil the statistical tests for being valid instruments. In the first stage, both IVs are highly significant. In the second stage, the Hansen J-test of overidentification is insignificant. Hence, both from a statistical as well as from an economic point of view, our instruments are valid. As displayed in Table A.4, the results of the IV estimation are in line with what we find in our matching estimation. 
Table A.4 Robustness test with instrumental variable regressions for $\mathrm{R} \& \mathrm{D}$ intensity.

\begin{tabular}{|c|c|c|}
\hline & First stage & Second stage \\
\hline \multicolumn{3}{|l|}{ Variables } \\
\hline & SUBSIDY & $2 S L S$ on $R \& D I N T$ \\
\hline \multirow[t]{2}{*}{ SUBSIDY_REG_IND (IV_1) } & $0.672 * * *$ & \\
\hline & $(0.058)$ & \\
\hline \multirow[t]{2}{*}{ CO_SCIE_IND (IV_2) } & $0.404 * * *$ & \\
\hline & $(0.118)$ & \\
\hline \multirow[t]{2}{*}{ SUBSIDY } & & $6.363 * * *$ \\
\hline & & (1.804) \\
\hline \multirow[t]{2}{*}{ PAST_SUBSIDY } & $0.330 * * *$ & 0.424 \\
\hline & $(0.034)$ & (1.719) \\
\hline \multirow[t]{2}{*}{ FIRMAGE } & 0.000 & $-0.005^{*}$ \\
\hline & $(0.000)$ & $(0.003)$ \\
\hline \multirow[t]{2}{*}{ FIRMAGE2 } & 0.000 & 0.000 \\
\hline & $(0.000)$ & $(0.000)$ \\
\hline \multirow[t]{2}{*}{ LNFIRMSIZE } & 0.003 & $-0.713 * *$ \\
\hline & $(0.012)$ & $(0.342)$ \\
\hline \multirow[t]{2}{*}{ LNFIRMSIZE2 } & 0.001 & 0.049 \\
\hline & $(0.001)$ & $(0.032)$ \\
\hline \multirow[t]{2}{*}{ PATCOUNT_E L } & 0.000 & $0.005 * * *$ \\
\hline & $(0.000)$ & $(0.002)$ \\
\hline \multirow[t]{2}{*}{ LNLABPROD } & $-0.012 * * *$ & $-0.636 * * *$ \\
\hline & $(0.004)$ & $(0.157)$ \\
\hline \multirow[t]{2}{*}{ FOREIGN } & $-0.020 *$ & 0.515 \\
\hline & $(0.011)$ & $(0.331)$ \\
\hline \multirow[t]{2}{*}{ EMPACA } & $0.002 * * *$ & $0.083^{* * *}$ \\
\hline & $(0.000)$ & $(0.020)$ \\
\hline \multirow[t]{2}{*}{ FIRMCOMP } & $0.000 * * *$ & $0.019 * * *$ \\
\hline & $(0.000)$ & $(0.005)$ \\
\hline \multirow[t]{2}{*}{ RDCOOP } & $0.135 * * *$ & 0.030 \\
\hline & $(0.011)$ & $(0.372)$ \\
\hline \multirow[t]{2}{*}{ TECHPOT } & $0.012 * * *$ & $0.235 * * *$ \\
\hline & $(0.003)$ & $(0.059)$ \\
\hline $\mathrm{N}$ & 6084 & 6084 \\
\hline Uncentered R2 & 0.291 & 0.232 \\
\hline F-Test of excl. instruments & $\begin{array}{c}\mathrm{F}(2,3551)= \\
71.52 * * *\end{array}$ & \\
\hline Hansen's J test statistic & & $\chi 2(1))=0.971$ \\
\hline
\end{tabular}

Note: IV_1 is the region and industry mean of the likelihood of receiving a subsidy. IV_2 is the industry sector mean of the likelihood of collaborating with science institutes. Both models include an intercept, time and industry dummies (not presented). Standard errors (in parentheses) are clustered at the firm level. *** (**,*) indicate a significance level of $1 \%(5 \%, 10 \%)$. 


\section{Appendix 3}

Robustness check for potential endogeneity of the collaboration variable in the innovation outcome equation

In our innovation outcome estimations, we face the problem that one of our main explanatory variable might be endogenous, namely our collaboration variables. In order to test if our results are affected by potential endogeneity, we conduct a structural equation approach introduced by Smith and Blundell (1986). For the sake of this robustness check, we defined two instrumental variables for our potential endogenous collaboration variable COOPPART following the advices of Murray (2006). Our first instrumental variable HAMP_IND, (IV_1) captures the importance of a wide range of hampering factors a firm is facing during its innovation activities, and is defined as the industry, firm size class and survey year mean of such hampering factors ${ }^{9}$. The underlying idea behind this instrument is that the higher the importance of manifold hampering factors is in close proximity in terms of technology and firm size class to a firm $i$ in a given year, the higher is the probability that the firm $i$ engages in a diversified collaboration pattern to counter these hampering factors. Our second instrumental variable KWSRC_IND (IV_2) is defined as the industry, survey year and firm size class mean of the diversity of knowledge sources used for conducting innovation activities. This instrument documents the reasoning that the more diverse knowledge sources are used for innovative activities in close proximity to a firm $i$, the higher the probability that the firm $i$ is engaged in collaboration agreements with divers types of partners ${ }^{10}$.

To further test the statistical validity of our instruments employed for the Blundell-Smith test of exogeneity, we ran a couple of tests on the validity of the chosen instruments. It should be noted though that we have to use the standard Two Stage Least Squares (2SLS) approach, as standard tests of over-identification do not exist for the Blundell-Smith approach. Our two excluded instruments are jointly statistical significant at the $1 \%$-level $(F(2,2930)=11.10)$, and the Hansen $\mathbf{J}$ test of over-identification cannot be rejected for radical innovation performance (Hansen $\mathrm{J}$ statistic $=.323, \mathrm{p}=.570$ ), nor for incremental innovation performance (Hansen $\mathrm{J}$ statistic $=.284, \mathrm{p}=.594)$. Finally, both our instruments are statistically significant in the first stage of the equation. Considering the above results, we can conclude that our two instrumental variables satisfy the statistical requirements.

As can be see seen in Table A.5, the first stage residuals are not significant in the innovation outcome equations. Therefore, we can conclude that our findings are not driven by endogeneity. 
Table A.5 Robustness test with instrumental variable regressions for innovation outcome.

\begin{tabular}{|c|c|c|c|}
\hline & First stage Probit: & Second stage Tobit: & Second stage Tobit: \\
\hline \multicolumn{4}{|l|}{ Variables } \\
\hline & COOPPART & RADICAL & INCREMENTAL \\
\hline \multirow[t]{2}{*}{ HAMP_IND (IV_1) } & $1.042 *$ & & \\
\hline & $(0.54)$ & & \\
\hline \multirow[t]{2}{*}{ KWSRC_IND (IV_2) } & $1.285^{* *}$ & & \\
\hline & $(0.57)$ & & \\
\hline \multirow[t]{2}{*}{ RDINT } & $0.027 * * *$ & $0.455^{* * *}$ & $0.367 * * *$ \\
\hline & $(0.01)$ & $(0.07)$ & $(0.08)$ \\
\hline \multirow[t]{2}{*}{ FIRMAGE } & 0.001 & $-0.067 * * *$ & $-0.075 * * *$ \\
\hline & $(0.00)$ & $(0.01)$ & $(0.02)$ \\
\hline \multirow[t]{2}{*}{ FIRMAGE2 } & 0.000 & $0.000 * * *$ & $0.000 * * *$ \\
\hline & $(0.00)$ & $(0.00)$ & $(0.00)$ \\
\hline \multirow[t]{2}{*}{ LNFIRMSIZE } & -0.035 & 0.913 & -0.354 \\
\hline & $(0.08)$ & $(1.02)$ & $(1.20)$ \\
\hline \multirow[t]{2}{*}{ LNFIRMSIZE2 } & $0.014 *$ & -0.087 & 0.044 \\
\hline & $(0.01)$ & $(0.10)$ & $(0.12)$ \\
\hline \multirow[t]{2}{*}{ FIRMCOMP } & $0.005 * * *$ & $0.040 * * *$ & $0.049 * * *$ \\
\hline & $(0.00)$ & $(0.01)$ & $(0.01)$ \\
\hline \multirow[t]{2}{*}{ TECHPOT } & $0.194 * * *$ & $1.698 * * *$ & $2.184 * * *$ \\
\hline & $(0.02)$ & $(0.33)$ & $(0.38)$ \\
\hline \multirow[t]{2}{*}{ COOPPART } & & 0.776 & -0.977 \\
\hline & & $(2.49)$ & $(2.83)$ \\
\hline \multirow[t]{2}{*}{$1^{\text {ST }}$ STAGE RESIDUALS } & & -0.316 & 0.979 \\
\hline & & (1.49) & (1.69) \\
\hline $\mathrm{N}$ & 4859 & 4859 & 4859 \\
\hline
\end{tabular}

Note: IV_1 considers the industry, survey year and firm size class mean of the importance of hampering factors a firm is facing to. IV_2 reflects the industry, survey year and firm size class mean of the diversity of knowledge sources used for innovation activities. The second stage Tobit models employ heteroscedastic-robust estimations. All stages include an intercept, time and industry dummies (not presented). Standard errors (in parentheses) are clustered at the firm level. $* * *(* *, *)$ indicate a significance level of $1 \%(5 \%, 10 \%)$. 


\section{References}

Aerts, K., \& Schmidt, T. 2008. Two for the price of one? Additionality effects of R\&D subsidies: A comparison between Flanders and Germany. Research Policy, 37(5): 806-822.

Aghion, P., \& Howitt, P. 1992. A Model of Growth through Creative Destruction. Econometrica, 60(2): 323-351.

Angrist, J. D. 1998. Estimating the labor market impact of voluntary military service using social security data on military applicants. Econometrica, 66(2): 249-288.

Arrow, K. J. 1962. Economic welfare and the allocation of resources for invention. In R. Nelson (Ed.), The Rate and Direction of Inventive Activity: 609-626: Princeton Univ. Press, Princeton, NJ.

Arrow, K. J., \& Lind, R. C. 1970. Uncertainty and the Evaluation of Public Investment Decisions. American Economic Review, 60(3): 364-378.

Beck, M., \& Schenker-Wicki, A. 2014. Cooperating with external partners: the importance of diversity for innovation performance. European J. International Management, 8: $548-569$.

Becker, W., \& Dietz, J. 2004. R\&D cooperation and innovation activities of firms - evidence for the German manufacturing industry. Research Policy, 33(2): 209-223.

Belderbos, R., Carree, M., Diederen, B., Lokshin, B., \& Veugelers, R. 2004a. Heterogeneity in $R \& D$ cooperation strategies. International Journal of Industrial Organization, 22(8-9): 1237-1263.

Belderbos, R., Carree, M., \& Lokshin, B. 2004b. Cooperative R\&D and firm performance. Research Policy, 33(10): 1477-1492.

Branstetter, L. G., \& Sakakibara, M. 2002. When Do Research Consortia Work Well and Why? Evidence from Japanese Panel Data. The American Economic Review, 92(1): 143-159.

Cerulli, G. 2010. Modelling and Measuring the Effect of Public Subsidies on Business R\&D: A Critical Review of the Econometric Literature. Economic Record, 86(274): 421449.

Cohen, W. M., \& Levinthal, D. A. 1990. Absorptive-Capacity - a New Perspective on Learning and Innovation. Administrative Science Quarterly, 35(1): 128-152.

CTI. 2011. CTI Activity Report 2011, Annual Reports. Bern: The Commission for Technology and Innovation.

CTI. 2013. CTI in figures Q1-Q2 2013, CTI in figures. Bern: The Commission for Technology and Innovation.

Czarnitzki, D., Ebersberger, B., \& Fier, A. 2007. The relationship between R\&D collaboration, subsidies and R\&D performance: Empirical evidence from Finland and Germany. Journal of Applied Econometrics, 22(7): 1347-1366.

Czarnitzki, D., \& Fier, A. 2003. Publicly funded R\&D collaborations and patent outcome in Germany: ZEW Discussion Papers.

Czarnitzki, D., \& Hussinger, K. 2004. The link between R\&D subsidies, R\&D spending and technological performance: ZEW Discussion Papers.

Czarnitzki, D., \& Licht, G. 2006. Additionality of public R\&D grants in a transition economy. Economics of Transition, 14(1): 101-131.

Czarnitzki, D., \& Lopes-Bento, C., forthcoming. Innovation subsidies: Does the funding source matter for innovation intensity and performance? Empirical evidence from Germany. Industry and Innovatoin. 
Czarnitzki, D., \& Lopes-Bento, C. 2012. Evaluation of public R\&D policies: a cross-country comparison. World Review of Science, Technology and Sustainable Development, 9(2-4): 254-282.

D'Aspremont, C., \& Jacquemin, A. 1988. Cooperative and Noncooperative R\&D in Duopoly with Spillovers. American Economic Review, 78(5): 1133-1137.

David, P. A., \& Hall, B. H. 2000. Heart of darkness: modeling public-private funding interactions inside the R\&D black box. Research Policy, 29(9): 1165-1183.

David, P. A., Hall, B. H., \& Toole, A. A. 2000. Is public R\&D a complement or substitute for private R\&D? A review of the econometric evidence. Research Policy, 29(4-5): 497529.

de Faria, P., Lima, F., \& Santos, R. 2010. Cooperation in innovation activities: The importance of partners. Research Policy, 39(8): 1082-1092.

DeBondt, R. 1997. Spillovers and innovative activities. International Journal of Industrial Organization, 15(1): 1-28.

Dehejia, R. H., \& Wahba, S. 2002. Propensity score-matching methods for nonexperimental causal studies. Review of Economics and Statistics, 84(1): 151-161.

Faems, D., Van Looy, B., \& Debackere, K. 2005. Interorganizational collaboration and innovation: Toward a portfolio approach. Journal of Product Innovation Management, 22(3): 238-250.

FSO. 2012. Public Funding of Research in Switzerland. In F. S. O. FSO (Ed.). Neuchâtel: Federal Statistical Office FSO.

Gerfin, M., \& Lechner, M. 2002. A microeconometric evaluation of the active labour market policy in Switzerland. Economic Journal, 112(482): 854-893.

Griliches, Z. 1979. Issues in Assessing the Contribution of Research and Development to Productivity Growth. Bell Journal of Economics, 10(1): 92-116.

Grilli, L., \& Murtinu, S. 2011. Econometric evaluation of public policies for science and innovation: a brief guide to practice. Science and Innovation Policy for the New Knowledge Economy: 60.

Hall, B. H., \& Maffioli, A. 2008. Evaluating the impact of technology development funds in emerging economies: evidence from Latin America. The European Journal of Development Research, 20(2): 172-198.

Heckman, J. J., LaLonde, R. J., \& Smith, J. A. 1999. The economics and econometrics of active labor market programs. Handbook of labor economics, 3: 1865-2097.

Hottenrott, H., \& Lopes-Bento, C. 2014a. (International) R\&D collaboration and SMEs: The effectiveness of targeted public R\&D support schemes. Research Policy, 43(6): 10551066.

Hottenrott, H., \& Lopes-Bento, C. 2014b. R\&D Partnerships and Innovation Performance: Can There be too Much of a Good Thing?, MSI Discussion paper 1415, Leuven.

Imbens, G. M., \& Wooldridge, J. M. 2008. Recent developments in the econometrics of program evaluation: National Bureau of Economic Research.

Jones, C. I., \& Williams, J. C. 1998. Measuring the social return to R\&D. Quarterly Journal of Economics: 1119-1135.

Kaiser, U. 2002. An empirical test of models explaining research expenditures and research cooperation: evidence for the German service sector. International Journal of Industrial Organization, 20(6): 747-774.

Kamien, M. I., Muller, E., \& Zang, I. 1992. Research Joint Ventures and Research-andDevelopment Cartels. American Economic Review, 82(5): 1293-1306.

Katz, M. L. 1986. An Analysis of Cooperative Research-and-Development. Rand Journal of Economics, 17(4): 527-543. 
Klette, T. J., Møen, J., \& Griliches, Z. 2000. Do subsidies to commercial R\&D reduce market failures? Microeconometric evaluation studies. Research Policy, 29(4-5): 471-495.

Laursen, K., \& Salter, A. 2006. Open for innovation: The role of openness in explaining innovation performance among UK manufacturing firms. Strategic Management Journal, 27(2): 131-150.

Lechner, M. 1999. Identification and Estimation of Causal Effects of Multiple Treatments Under the Conditional Independence Assumption, IZA DP No. 91, Discussion paper ed. Forschungsinstitut zur Zukunft der Arbeit Institute for the Study of Labor.

Leiponen, A., \& Helfat, C. E. 2010. Innovation Objectives, Knowledge Sources, and the Benefits of Breadth. Strategic Management Journal, 31(2): 224-236.

Martin, S., \& Scott, J. T. 2000. The nature of innovation market failure and the design of public support for private innovation. Research Policy, 29(4-5): 437-447.

Murray, M. P. 2006. The bad, the weak, and the ugly: Avoiding the pitfalls of instrumental variables estimation. Available at SSRN 843185.

Nelson, R. R. 1959. The Simple Economics of Basic Scientific-Research. Journal of Political Economy, 67(3): 297-306.

OECD. 1992. Proposed guidelines for collecting and interpreting technology innovation data. Oslo Manual. Paris: Organisation for Economic Co-operation and Development.

OECD. 2012. OECD Science, Technology and Industry Outlook 2012: OECD Publishing.

Romer, P. M. 1990. Endogenous Technological-Change. Journal of Political Economy, 98(5): S71-S102.

Rosenbaum, P. R., \& Rubin, D. B. 1985. Constructing a Control-Group Using Multivariate Matched Sampling Methods That Incorporate the Propensity Score. American Statistician, 39(1): 33-38.

Rubin, D. B. 1977. Assignment to Treatment Group on the Basis of a Covariate. Journal of Educational and Behavioral statistics, 2(1): 1-26.

Sakakibara, M. 2001. The diversity of R\&D consortia and firm behavior: Evidence from Japanese data. Journal of Industrial Economics, 49(2): 181-196.

Salter, A. J., \& Martin, B. R. 2001. The economic benefits of publicly funded basic research: a critical review. Research policy, 30(3): 509-532.

Smith, J. A., \& Todd, P. E. 2005. Does matching overcome LaLonde's critique of nonexperimental estimators? Journal of Econometrics, 125(1-2): 305-353.

Smith, R. J., \& Blundell, R. W. 1986. An exogeneity test for a simultaneous equation Tobit model with an application to labor supply. Econometrica: Journal of the Econometric Society: 679-685.

Tobin, J. 1958. Estimation of Relationships for Limited Dependent-Variables. Econometrica, 26(1): 24-36.

Wallsten, S. J. 2000. The effects of government-industry R\&D programs on private R\&D: the case of the Small Business Innovation Research program. Rand Journal of Economics, 31(1): 82-100.

Wooldridge, J. M. 2010. Econometric analysis of cross section and panel data: MIT press. 


\section{Notes}

${ }^{1}$ Data about project duration is provided by ARAMIS, a database of the Swiss federal administration.

${ }^{2}$ See Czarnitzki and Lopes-Bento (2012) for an overview on relevant recent empirical studies; Cerulli (2010) for a critical overview on the different applied methods.

${ }^{3}$ In terms of subsidized collaboration, exceptions are Sakakibara (2001) and Branstetter and Sakakibara (2002) who analysed Japanese government-sponsored R\&D consortia and find evidence that participating firms have higher R\&D expenditures as well as more patents. Czarnitzki et al. (2007) find positive effects of collaboration for subsidized firms with respect to R\&D expenditures and patents. Indeed, many studies have considered patent application as outcome variable. Even though patents provide an acknowledged measure for a new technology with an important inventive step (provided that those patents end up being granted), a patent constitutes the first step of a new product and is still several steps away form a successful market innovation. Hottenrott and Lopes-Bento (2014a), who are interested in the market potential of publicly induced $R \& D$, do not differentiate between the degree of novelty of the outcome of the innovation. Likewise, while the authors take into account the impact of collaboration (differentiating between national and international collaboration) they do not differentiate between the number of different partners or the type of partners a firm is involved in.

${ }^{4}$ We bootstrap the entire procedure (inclusive of the matching) 150 times, allowing us to estimate how the sample mean of our actual sample varies due to random sampling.

${ }^{5}$ The definition of R\&D expenditures as well as of radical and incremental innovation follows the OECD guidelines (OECD, 1992).

${ }^{6}$ We estimated the same model, aggregating the various collaboration partners into vertical, horizontal and diagonal (science) collaboration. The results remain the same. Only vertical collaboration was statistically significant, and negatively so. We thus do not present the detail of the results in the table.

${ }^{7}$ We have aggregated the different types of partner into vertical, horizontal and science collaboration partners (CO_VER, CO_HOR, CO_SCIE) in the tobit regressions as the results are not impacted by this aggregation.

${ }^{8} \mathrm{He}$ have further allowed for a longer time lag between either type of R\&D investment and innovation output. Conclusions remain unchanged. The detailed regression results can be obtained from the authors upon request.

${ }^{9}$ We consider 22 different hampering factors which firms might face in their innovation activities. These hampering factors might have negative consequences on the successful realization of innovation projects and can be attributed to categories like high risks and high costs, ease of imitating, financial constraints, lack of skilled employees, lack of knowledge, organizational obstacles, as well as further institutional obstacles.

${ }^{10}$ Relevant sources of knowledge which are captured in this variable constitute knowledge from other firms (costumers, suppliers, competitors, etc.), research institutions, consultancies, technological transfer agencies, and from other general available information (patent disclosures, conferences and exhibitions, scientific and technical literature, IT-supported information systems). 